\title{
Biological soil crusts impress vegetation patches and fertile islands over an arid pediment, Iran
}

\author{
Adel Sepehr ${ }^{1 *(\mathbb{D})}$, Asma Hosseini', Kamal Naseri2 (iD) and Atoosa Gholamhosseinian' (1D \\ 'Department of Desert and Arid Zones Management, Ferdowsi University of Mashhad, Mashhad 0098513, Iran \\ 2Department of Rangelands and Watershed Management, Ferdowsi University of Mashhad, Mashhad 0098513, Iran
}

\section{ARTICLE INFO}

Received October 27, 2021

Revised December 6, 2021

Accepted December 7, 2021

Published on February 10, 2022

*Corresponding author

Adel Sepehr

E-mail adelsepehr@um.ac.ir

The authors of this article dedicate the present manuscript to Asma whose name also means heavens. She left us to meet God in the Heavens.

\begin{abstract}
Background: Plant vegetation appears in heterogeneous and patchy forms in arid and semi-arid regions. In these regions, underneath the plant patches and the empty spaces between them are covered by biological soil crusts (moss, lichen, cyanobacteria, and fungi). Biological soil crusts lead to the formation and development of fertile islands in between vegetation patches via nitrogen and carbon fixation and the permeation of runoff water and nutrients in the soil.

Results: The present study has investigated the association of biological soil crusts, the development of fertile islands, and the formation of plant patches in part of the Takht-e Soltan protected area, located in Khorasan Razavi Province, Iran. Three sites were randomly selected as the working units and differentiated based on their geomorphological characteristics to the alluvial fan, hillslope, and fluvial terrace landforms. Two-step systematic random sampling was conducted along a 100-meter transect using a $5 \mathrm{~m}^{2}$ plot at a $0-5$ $\mathrm{cm}$ depth in three repetitions. Fifteen samplings were carried out at each site with a total of 45 samples taken. The results showed that the difference in altitude has a significant relationship with species diversity and decreases with decreasing altitude. Results have revealed that the moisture content of the site, with biocrust has had a considerable increase compared to the other sites, helping to form vegetation patterns and fertile islands.

Conclusions: The findings indicated that biological crusts had impacted the allocation of soil parameters. They affect the formation of plant patches by increasing the soil's organic carbon, nitrogen, moisture and nutrient content provide a suitable space for plant growth by increasing the soil fertility in the inter-patch space.
\end{abstract}

Keywords: biological soil crusts, fertile islands, soil physicochemical parameters, vegetation patches

\section{Introduction}

The ecosystems of arid and semi-arid regions worldwide are known for their sparse vegetation and scarce biological resources (Toranjzar et al. 2009). Plants are non-homogeneously distributed in these regions and centralized in areas where water and nutrients are concentrated. Nutrients are scant in these regions and these thinly dispersed resources are not distributed evenly and continuously. Therefore, a phenomenon known as resource redistribution causes patchiness in vegetation (Ludwig et al. 2007). Plant patches are richer in terms of nutrients and more suitable conditions in terms of soil properties such as permeability, nutrient accumulation, and stability, thus called "fertile patches". They act as an oasis or shelter during environmental stresses and have therefore been named "fertile is- lands" (Bolling and Walker 2002; Schlesinger et al. 1990). These islands have a major impact on changes in desert ecosystems through redistribution and dispersion of food resources under vegetation canopy and their accumulation in the root zone (Walker et al. 2001). Also, the presence of these islands leads to an increase in the amount of some soil parameters such as nitrogen (Bonanomi et al. 2008), phosphorus and other nutrients in the space under the canopy, which has a positive effect on plant growth (Bolling and Walker 2002; Walker et al. 2001; Zhao et al. 2010). There are empty vegetation-free spaces between the spots where resources such as water and soluble nutrients move freely between the spaces. This movement occurs along the downward slope when water is the actuator or along the wind direction when the wind is the actuator. Thus, islands are richer in nutrients (Thompson et al. 2005). In 
many desert ecosystems, voids between vascular plants are covered with biological crusts (Bowker et al. 2008; Bowker et al. 2010).

Biological crusts comprise a broad range of microorganisms including cyanobacteria, algae, lichen, moss, and fungi. These organisms live a few millimeters beneath, or on the soil surface in the free spaces between vascular plants and are referred to as autotrophs (Belnap 2003; Belnap and Büdel 2016). Biocrust can lead to optimal plant growth (Condon and Pyke 2018a). The positive effect of cyanobacteria on the germination and growth of wheat and rice seeds has been reported (Muñoz-Rojas et al. 2018). Furthermore, the use of cyanobacteria on seeds can also have beneficial effects on germination (O'Callaghan and van Sinderen 2016). The chemicals' produced by cyanobacteria have essential roles in regulating metabolism, plant growth, development, and improving germination (Hashtroudi et al. 2013). Considering the importance, role and function of soil biological crusts in the development of fertile islands and plant establishment, the aim of this study was to investigate the effect of biological crusts on the development of fertile islands and vegetation formation in various landforms in arid and semi-arid regions. The relationship between the development of fertile islands through biological soil crusts and the development and establishment of vegetation can be used as an efficient solution to prevent desertification.

\section{Materials and Methods}

\section{Studied area}

This research has been conducted in the Takht-e Soltan area, located in Khorasan Razavi Province, northeastern Iran, with an arid and semi-arid climate. Takht-e Soltan is located in the south-west of Sarakhs plain with a geographical longitude of $36^{\circ} 16^{\prime}$ to $61^{\circ} 58^{\prime} 20^{\prime \prime} \mathrm{E}$ and latitude of $60^{\circ} 59^{\prime}$ to $36^{\circ} 15^{\prime} \mathrm{N}$ (Fig. 1). The average annual rainfall in this region is $202 \mathrm{~mm}$, which is the highest and lowest rainfall in February and July, respectively. The yearly minimum temperature is $1^{\circ} \mathrm{C}$. and the highest temperature is $28.4^{\circ} \mathrm{C}$ in July. The average annual temperature is $27^{\circ} \mathrm{C}$. The studied region is located in a topographic and geomorphic gradient of an erosional pediment. In terms of topography, the region consists of alluvial fans, hillslopes, and an erosional pediment. The particle size distribution in the soil shows sandy loam textures.

Rocks are mostly sandstone, conglomerate and shale. This area is geologically and geomorphologically related to the Quaternary and Cenozoic periods.

\section{Sampling and laboratory analysis}

\section{Sampling}

Soil sampling was carried out in autumn 2018 via plot and transect method and as a systematic random sampling using a 100 -meter transect and five $5 \mathrm{~m}^{2}$ plots with $20-\mathrm{m}$ distancing, and $1 \mathrm{~m}^{2}$ subplots. Sampling was performed at three sites (fluvial terrace, hillslope, and alluvial fan) and

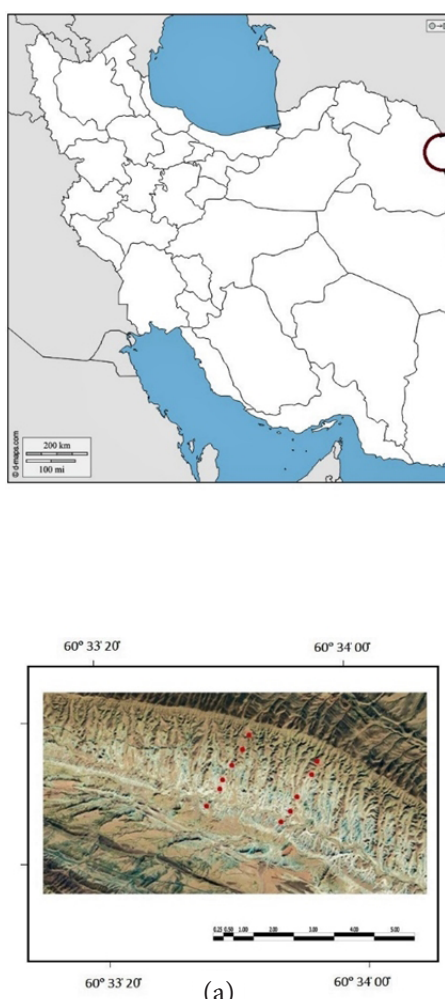

(a)

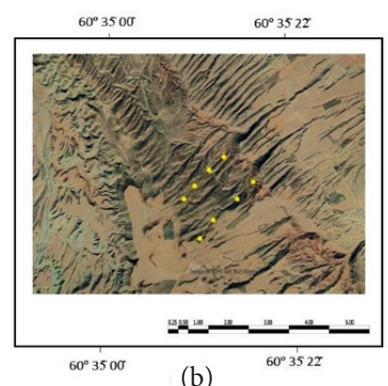

(b) $60^{\circ} 3320$

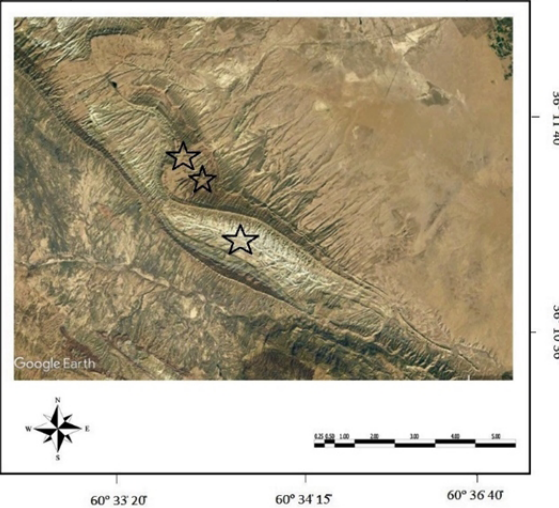

$60^{\circ} 3575$

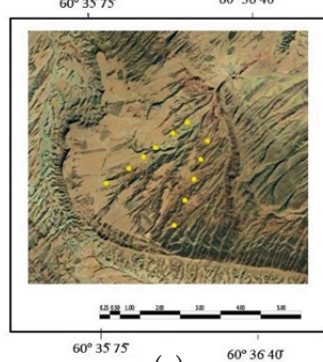

(c)
Fig. 1 Study sites: Above image, general area of Takht-e Soltan. (a) Alluvial fan site, (b) hill slope sites, and (c) alluvial terrace sites. 
0-5 cm depth from the soil surface. In each site, two transects and five plots (in each transect) were sampled in three repetitions.

\section{Laboratory analysis}

Soil samples were transferred to the laboratory to investigate and measure chemical and physical parameters. Soil electrical conductivity in a soil extract with a ratio of 1:5 by an EC (electrical conductivity) meter (Rayment and Lyons 2011), the relative percentage of soil particles (hydrometer 52H) (Bouyoucos 1962), calcium carbonate (Nelson and Sommers 1983), organic carbon (Mingorance et al. 2007), power of hydrogen with a 1:2.5 extract using a $\mathrm{pH}$-meter (Olsen 1954), total nitrogen (Bremner and Mulvaney 1983), Soil aggregate stability (Lax et al. 1994), bulk density via the paraffin coated clod method, phosphorus (Olsen 1954), potassium and sodium (Knudsen et al. 1983), and the moisture content via the weight method.

Scanning electron microscopy imaging was performed in the central laboratory of Ferdowsi University of Mashhad. This microscope enables the examination and analysis of chemical, composition, surface, and internal substructure properties in micronic and nanometric dimensions. The samples are thoroughly dried and covered with a thin layer of gold or gold alloy before taking images with the device. EDS spectrometry enables the quantitative and qualitative examination of the samples by measuring the energy of the X-rays emitted from the sample (Goldstein et al. 2018).

\section{Investigating the biodiversity of biological soil crusts and vegetation}

The identification of lichens was carried out via morphological examination using a stereomicroscope and using valid identification keys (McCune et al. 2012; Rosentreter et al. 2007; Temina and Nevo 2009; Zedda 2000). To measure the percentage of vegetation, $5 \mathrm{~m}^{2}$ plots and $1 \mathrm{~m}^{2}$ subplots were used along the $100 \mathrm{~m}$ transect and the plant species at each site were collected and transferred to the laboratory of the Faculty of Natural Resources and Environment for identification. The biological crusts and plants were identified to investigate the biodiversity of the species, in contrast, the species richness function, the Shannon index, and the Simpson index were used to evaluate species biodiversity. 'Simpson's Diversity Index $(\lambda)$ ': This index shows the probability that two individuals, randomly selected from the same place or at the same time, belong to two separate species. In ecology, it is mostly used to determine the level of biodiversity in a habitat and is as follows (relation 1) (Simpson 1949). Calculation: In this regard, 1D: Simpson diversity index (variation range $0-1$ ), $n_{i}$ : number of people of each species at each sampling, $\mathrm{N}$ : total number of sample people, and S: number of species in the sample

$$
1-D=1-\sum_{i=1}^{s}\left[\frac{n_{i}\left(n_{i}-1\right)}{N(N-1)}\right]
$$

Shannon-Wiener index ( $\left.\mathrm{H}^{\prime}\right)$ : The issues of logarithmic series are easily solved with this index and it is the most prevalent method for measuring diversity (Shannon 1948). The value of this index increases with the increase of the number of species in the community and could theoretically reach very high numbers (Hayat et al. 2010). Calculation: In this regard, H': Shannon-Wiener diversity index, S: number of species in the sample, and $P_{i}$ : ratio of the number of species, i: to the total number of species

$$
H^{\prime}=-\sum_{i=1}^{s}\left(P_{i}\right)\left(\log _{2} P_{i}\right)
$$

\section{Statistical analysis}

The analysis of data was performed using SPSS V26 statistical software (IBM Co., Armonk, NY, USA). The Kolmogorov-Smirnov test was used to investigate the normality of parameters, and data correlation was calculated with respect to Pearson's correlation value. The existence of a correlation between environmental factors, the soil's physicochemical properties, the presence of biological crusts, and vegetation density was investigated. In the case of a significant correlation between the data, the data were stated as being positive or negative. In the case of a positive correlation, it is deducted that considering the data in each site, the measured parameters are dependent on each other. Then, the significant difference of the groups was investigated via analysis of variance and Duncan's multiple-range post-hoc method at a statistical level of $5 \%$.

\section{Results}

\section{Biological soil crusts and vegetation in the three landforms studied}

The total percentage of the biological soil crusts in the alluvial fan site (Total mean [\%] $=52.50 \%$ ) is relatively average and its predominant includes lichens (Table 1, Fig. 2). Biological crusts were not observed in the other two landforms.

In Table 2, the species richness index for the alluvial fan site is listed by height classes. Examination of the values of Simpson species diversity indices (Hill diversity index 2) in the table shows that significantly $770 \mathrm{~m}$ has a maximum, $752 \mathrm{~m}$ has a minimum and 766, 762, and $759 \mathrm{~m}$ are the intermediate values of the species diversity index. In general, it can be concluded that the diversity of species has decreased with decreasing altitude.

The vegetation of the hillslope site was relatively moderate (total mean $=6.5 \%$ ) and its predominant vegetation was Polygonum patulum and Peganum harmala. Moreover, the 
Table 1 Classification of lichens and cyanolichens of the studied site

\begin{tabular}{|c|c|c|c|c|}
\hline Crust type & Category & Order & Family & Species \\
\hline \multirow[t]{2}{*}{ Lichens with cyanobacterial photobiont } & Lecanoromycetes & Lecanorales & Collemataae & Collema \\
\hline & Chaetothyriomycetidae & Verrucariales & Verrucariace & Endocaon \\
\hline \multirow[t]{3}{*}{ Lichens with photobiont algae green } & Lecanoromycetes & & Psoraceae & Psora \\
\hline & & Lecanorales & Ramalinacee & Toninia \\
\hline & & Candelariales & Candelariace & Candelaella \\
\hline
\end{tabular}

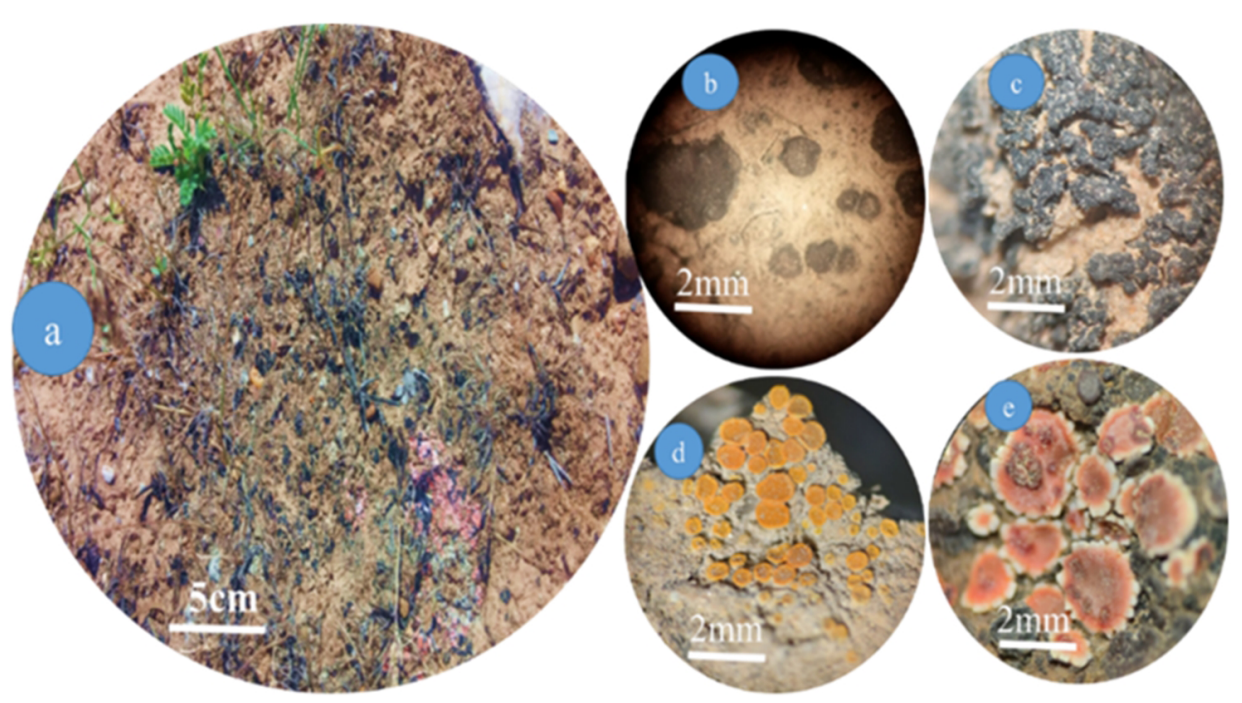

Fig. 2 Soil biocrusts photographed during a field visit to the area. picture (a) shows a view of lichens and cyan lichens. picture (b) and (c) show close-ups of cyanolichens endocarpon sp. and collema sp, respectively, taken by a stereomicroscope; picture (d) and (e) are close-ups of the lichens of Psora $s p$. and Candelariella sp, taken by a stereomicroscope.

Table 2 Biological soil crust species richness and species diversity by Shannon and Simpson's indices in alluvial fan site (by height class)

\begin{tabular}{|c|c|c|c|c|c|c|c|}
\hline \multirow{2}{*}{ Site } & \multicolumn{5}{|c|}{ Height } & \multirow{2}{*}{$p$-value } & \multirow{2}{*}{ Test $\mathrm{F}$} \\
\hline & 770 meters & 766 meters & 762 meters & 759 meters & 752 meters & & \\
\hline Species richness index & $0.707 \pm 3.500^{\mathrm{a}}$ & $0.00 \pm 3.000^{a}$ & $2.000 \pm 1.440^{\mathrm{a}}$ & $2.000 \pm 0.000^{a}$ & $2.00 \pm 0.000^{a}$ & 0.233 & 2.000 \\
\hline Shannon diversity index & $0.188 \pm 5.710^{\mathrm{a}}$ & $0.007 \pm 6.280^{\mathrm{a}}$ & $3.640 \pm 3.109^{a}$ & $2.770 \pm 1.092^{\mathrm{a}}$ & $3.16 \pm 0.193^{\mathrm{a}}$ & 0.195 & 2.281 \\
\hline Simpson diversity index & $0.005 \pm 0.017^{\mathrm{a}}$ & $0.00007 \pm 0.009^{\mathrm{a}, \mathrm{b}}$ & $0.008 \pm 0.000^{a, b}$ & $0.007 \pm 0.000^{\mathrm{a}, \mathrm{b}}$ & $0.006 \pm 0.001^{\mathrm{b}}$ & 0.044 & 5.583 \\
\hline
\end{tabular}

Values are presented as mean \pm standard deviation.

Within given parameters, different superscripts indicate a significant among sites, respectively, at $p<0.05$.

total vegetation percentage of the fluvial terrace was relatively low (total mean $=2.2 \%$ ) and the predominant vegetation was Alhagi camelorum, Peganum harmala, and Acanthophyllum glandulosum (Table 3). The results of Simpson species diversity index (Hill diversity index 2) (Table 4) show that the difference in altitude has a significant relationship with species diversity and decreases with decreasing altitude. There was no significant difference between the Shannon-Wiener species diversity index and number of species index in altitude groups. The total vegetation percentage of the alluvial fan site was relatively high (total mean $=16.5 \%$ ), (Fig. 3) its predominant vegetation consisted of various Artemisia species and Poa bulbosa, and the soil texture was loam.

The results of Duncan's test, Shannon-Wiener species diversity indices, and the species richness index of the vegetation (Table 4) show that significantly speaking, species biodiversity is of the maximum value for the alluvial fan site, intermediate value for the fluvial terrace site, and minimum value for the hillslope site. The results indicate no significant difference regarding Simpson's diversity index.

\section{Effect of biological crusts on soil fertility and plant patch formation}

The results obtained from the analysis of variance, Duncan's multiple-range method, and Pearson's multiple correlation test, presented separately for each site, are as follows:

According to Duncan's comparison of means (Table 5), the vegetation of the alluvial fan site was better and more, compared to the other studied sites, and regarding the soil's physicochemical properties (Table 5), the mentioned site has a significantly $(p<0.05)$ higher organic carbon, organic matter, and nitrogen content, as compared to the other sites, but ranks lower regarding the $\mathrm{pH}, \mathrm{EC}$, apparent density, and sand content. Furthermore, the results of the soil samples confirmed a significantly $(p<0.05)$ higher 
Table 3 The following table shows the plant species, the dominant species and the percentage of vegetation cover at different sites

\begin{tabular}{|c|c|c|c|}
\hline Site & Species vegetation & Dominant species & Mean total vegetation cover \\
\hline Alluvial fan & $\begin{array}{l}\text { Londesia eriantha } \\
\text { Poa bulbosa } \\
\text { Artemisia scoparia } \\
\text { A. kopetdayhensis } \\
\text { Gagea lutea } \\
\text { Amygdalus lycioides } \\
\text { Centaurea virgate } \\
\text { Peganum harmala }\end{array}$ & $\begin{array}{l}\text { Artemisia scoparia } \\
\text { A. kopetdayhensis } \\
\text { Poa bulbosa }\end{array}$ & $16.5 \%$ \\
\hline Hillslope & $\begin{array}{l}\text { Amygdalus lycioides } \\
\text { Polygonum patulum } \\
\text { Peganum harmala } \\
\text { Alhagi camelorum }\end{array}$ & $\begin{array}{l}\text { Polygonum patulum } \\
\text { Peganum harmala }\end{array}$ & $6.5 \%$ \\
\hline Terrace alluvial & $\begin{array}{l}\text { A. kopetdayhensis } \\
\text { A. scoparia } \\
\text { Alhagi camelorum } \\
\text { Peganum harmala } \\
\text { L. eriantha } \\
\text { Stenophylla carex } \\
\text { Acanthophyllum glandulosum } \\
\text { Fumaria officinalis } \\
\text { Euphorbia helioscopia } \\
\text { Alyssum minus }\end{array}$ & $\begin{array}{l}\text { Alhagi camelorum } \\
\text { Peganum harmala } \\
\text { Acanthophyllum glandulosum }\end{array}$ & $2.2 \%$ \\
\hline
\end{tabular}

Table 4 Plant species richness (total per site), species diversity (Shannon and Simpson' indices) in three studied sites

\begin{tabular}{lrrrrr}
\hline \multicolumn{1}{c}{ Site } & Alluvial fan & Hill slop & Terrace alluvial fans & $p$-value & Test F \\
\hline Species richness index & $4.200 \pm 0.477^{\mathrm{a}}$ & $1.800 \pm 0.477^{\mathrm{b}}$ & $3.600 \pm 2.302^{\mathrm{a}, \mathrm{b}}$ & 0.044 & 4.105 \\
Shannon diversity index & $11.469 \pm 1.800^{\mathrm{a}}$ & $3.426 \pm 1.108^{\mathrm{b}}$ & $10.117 \pm 8.720^{\mathrm{a}, \mathrm{b}}$ & 0.037 & 4.374 \\
Simpson diversity index & $0.109 \pm 0.082^{\mathrm{a}}$ & $0.230 \pm 0.160^{\mathrm{a}}$ & $0.265 \pm 0.411^{\mathrm{a}}$ & 0.618 & 0.501 \\
\hline
\end{tabular}

Values are presented as mean \pm standard deviation.

Within a given parameters, different superscripts indicate a significant among sites, respectively, at $p<0.05$.

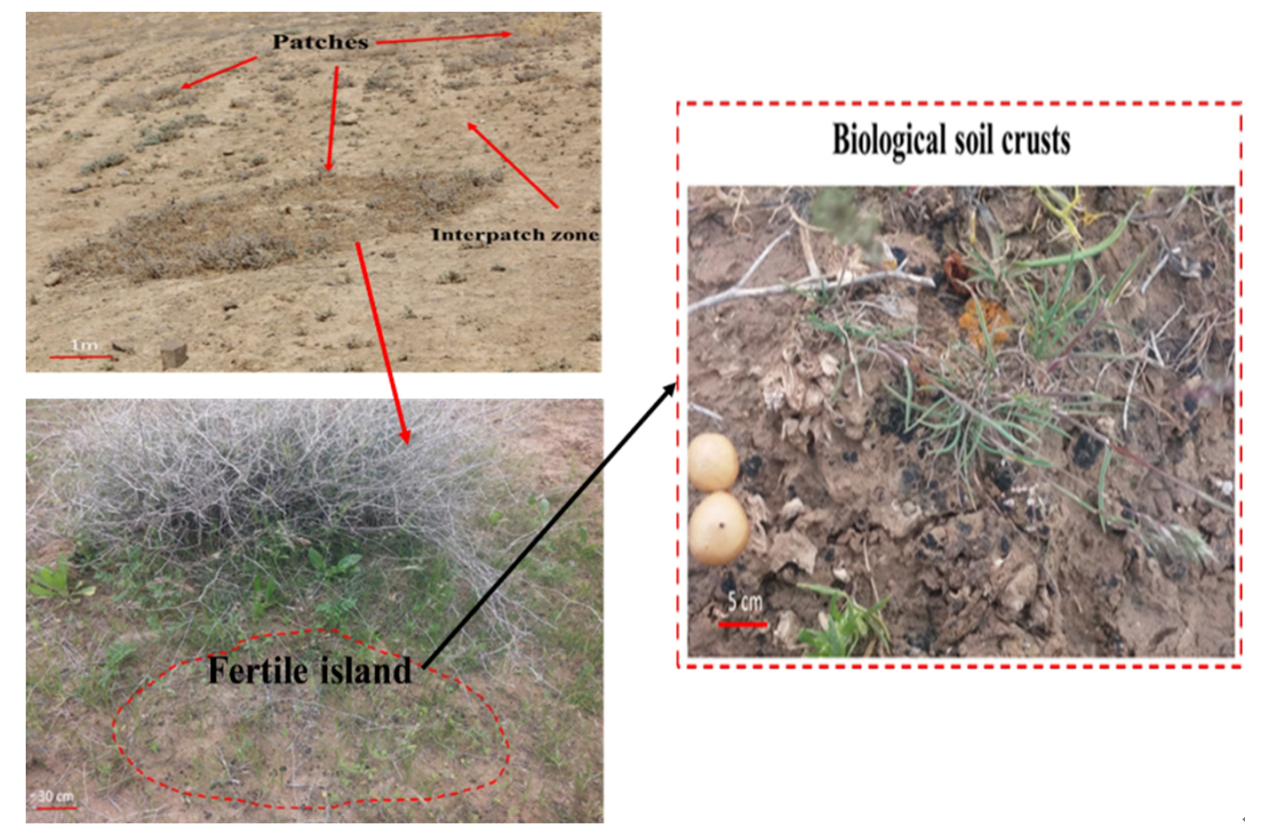

Fig. 3 The image shows the role of biological soil crusts in the development of fertile islands and vegetation patches. level of calcium carbonate, potassium, phosphorus, and silt content. Investigating Pearson's correlation (coefficient of correlation $=\mathrm{R}$ ) in this site indicated that the percentage of crust cover has the highest level of correlation with the absorbable phosphorus at a 95\% level $(\mathrm{R}=0.948, p=0.05)$ and the highest level of positive correlation with the vege- 
Table 5 Analysis of variance of physicochemical and biological soil properties $(n=45)$

\begin{tabular}{|c|c|c|c|c|c|}
\hline Factors soil physicochemical properties & $\mathrm{F}$ & $p$-value & Alluvial fan & Hillslope & Alluvial terrace \\
\hline $\mathrm{pH}^{*}$ & 12.127 & 0.001 & $8.162 \pm 0.263^{b}$ & $8.480 \pm 0.072^{\mathrm{a}}$ & $8.716 \pm 0.146^{a}$ \\
\hline $\mathrm{EC}^{*}(\mu \mathrm{S} / \mathrm{cm})$ & 4.917 & 0.028 & $171.440 \pm 78.670^{\mathrm{b}}$ & $273.168 \pm 15.503^{\mathrm{a}, \mathrm{b}}$ & $562.606 \pm 345.305^{\mathrm{a}}$ \\
\hline Soil bulk density ${ }^{*}\left(\mathrm{~g} / \mathrm{cm}^{3}\right)$ & 18.904 & $<0.001$ & $1.306 \pm 0.080^{\mathrm{b}}$ & $1.658 \pm 0.133^{b}$ & $2.564 \pm 0.557^{\mathrm{a}}$ \\
\hline Soil water content ${ }^{*}(\%)$ & 4.571 & 0.033 & $145.190 \pm 1.600^{a}$ & $134.120 \pm 9.250^{\mathrm{b}}$ & $136.010 \pm 5.180^{c}$ \\
\hline Organic matter ${ }^{*}(\%)$ & 13.189 & 0.001 & $2.156 \pm 0.986^{\mathrm{a}}$ & $0.714 \pm 0.093^{b}$ & $0.388 \pm 0.162^{c}$ \\
\hline Organic carbon* $\left.{ }^{*} \%\right)$ & 13.301 & 0.001 & $1.238 \pm 0.564^{\mathrm{a}}$ & $0.408 \pm 0.055^{\mathrm{b}}$ & $0.222 \pm 0.091^{\mathrm{b}}$ \\
\hline $\mathrm{TKN}^{*}(\%)$ & 142.742 & $<0.001$ & $0.066 \pm 0.001^{\mathrm{a}}$ & $0.035 \pm 0.004^{b}$ & $0.0263 \pm 0.005^{c}$ \\
\hline $\mathrm{P}^{*}(\mathrm{mg} / \mathrm{kg})$ & 23.692 & $<0.001$ & $0.001 \pm 0.000^{\mathrm{a}}$ & $0.001 \pm 0.000^{\mathrm{b}}$ & $0.000 \pm 0.000^{c}$ \\
\hline $\mathrm{K}^{*}(\mathrm{mg} / \mathrm{kg})$ & 28.324 & $<0.001$ & $0.002 \pm 0.000^{\mathrm{a}}$ & $0.002 \pm 0.000^{b}$ & $0.001 \pm 0.000^{c}$ \\
\hline $\mathrm{Na}(\mathrm{mg} / \mathrm{kg})$ & 1.322 & 0.303 & $0.001 \pm 0.003^{\mathrm{a}}$ & $0.001 \pm 0.000^{\mathrm{a}}$ & $0.001 \pm 0.001^{\mathrm{a}}$ \\
\hline $\mathrm{CaCO}_{3}^{*}(\%)$ & 7.024 & 0.010 & $40.700 \pm 12.500^{\mathrm{a}}$ & $21.670 \pm 3.630^{\mathrm{b}}$ & $37.151 \pm 7.020^{\mathrm{a}}$ \\
\hline Clay (\%) & 0.866 & 0.445 & $26.400 \pm 4.560^{\mathrm{a}}$ & $22.400 \pm 8.050^{\mathrm{a}}$ & $22.400 \pm 2.610^{\mathrm{a}}$ \\
\hline Sand ${ }^{*}(\%)$ & 7.065 & 0.009 & $36.800 \pm 5.210^{\mathrm{b}}$ & $52.000 \pm 7.350^{\mathrm{a}}$ & $61.200 \pm 15.530^{\mathrm{a}}$ \\
\hline Silt ${ }^{*}(\%)$ & 5.205 & 0.024 & $36.800 \pm 7.150^{a}$ & $25.600 \pm 8.880^{a, b}$ & $16.400 \pm 13.070^{\mathrm{b}}$ \\
\hline Aggregate stability ${ }^{*}(\%)$ & 23.798 & $<0.001$ & $28.652 \pm 27.010^{c}$ & $92.302 \pm 11.360^{\mathrm{b}}$ & $131.684 \pm 29.070^{\mathrm{a}}$ \\
\hline Total vegetation cover $^{*}(\%)$ & 19.082 & $<0.001$ & $16.500 \pm 5.950^{\mathrm{a}}$ & $6.500 \pm 2.280^{\mathrm{b}}$ & $2.160 \pm 1.360^{b}$ \\
\hline
\end{tabular}

Values are presented as mean \pm standard deviation.

Analyzed with the two-way ANOVA for Duncan post-hoc test.

*Represent significant at $95 \%$ confidence interval or $p<0.05$.
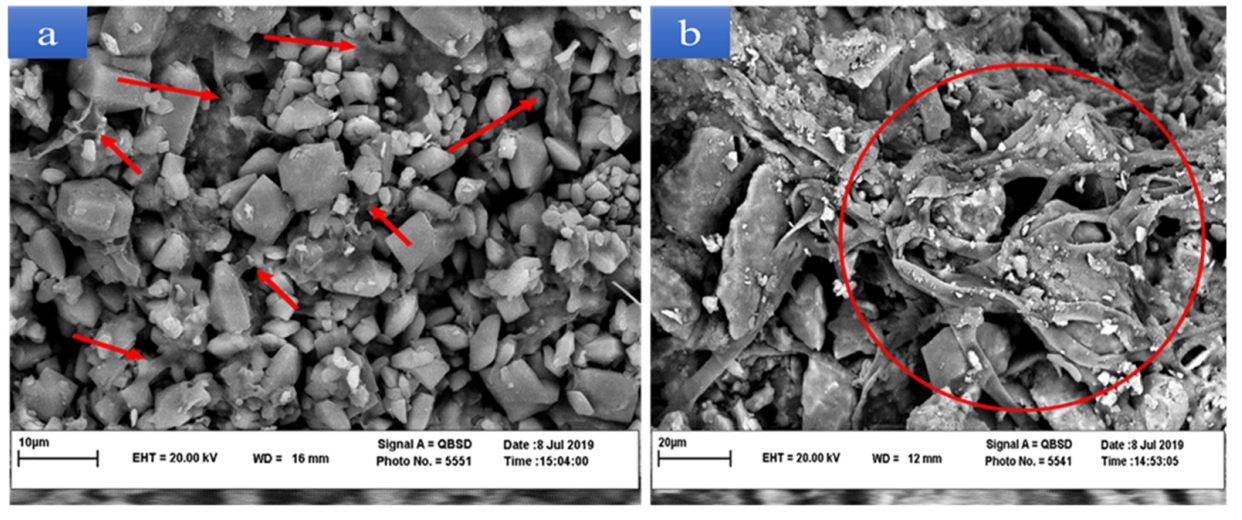

Fig. 4 The prepared SEM (scanning electron microscope) images show the stability of the aggregates. (a) Shows the red arrows, the viscous polysaccharides that bind the aggregates together. (b) Shows the fungal hyphae and they protect the soil aggregates like a net. tation percentage at a $99 \%$ level $(\mathrm{R}=0.996, p=0.01)$. The highest level of vegetation density, with a significant difference, is observed in this site.

In the hillslope site, almost all the soil's properties are at an intermediate level in between the values obtained for the two other sites. The results showed significantly higher levels $(p<0.05)$ of nitrogen, potassium, phosphorus, organic carbon, and organic matter content compared to the fluvial site. Also, the results obtained from the soil samples of this site showed significantly $(p<0.05)$ lower levels of calcium carbonate content compared to the fluvial terrace. According to Pearson's correlation, the results indicate that the vegetation percentage of this site has a positive correlation $(\mathrm{R}=0.948, p=0.05)$ with the total nitrogen content. The fluvial terrace was almost devoid of vegetation. The region's soil has significantly $(p<0.05)$ lower nitrogen, phosphorus, potassium, organic carbon, and organic matter content compared to the other studied sites. This site also has a significantly $(p<0.05)$ lower EC, as compared to the other sites. The results obtained from Pearson's correlation analysis show that the vegetation percentage of the studied site has a positive correlation $(p<0.05)$ with the total nitrogen, organic matter, organic carbon, and absorbable phosphorus content. Figure 4 shows an electron microscope image of the presence of biological crusts at the alluvial fan site. As can be seen in the image, the presence of these crusts causes the soil particles to coalesce, Figure $4 \mathrm{~b}$ shows the polysaccharides produced by these crusts that hold the soil particles together.

\section{Discussion}

\section{Comparison of physical and chemical parameters of soil in the presence and absence of biological crusts in three landforms}

In this study, many soil parameters such as $\mathrm{N}, \mathrm{OC}, \mathrm{P}, \mathrm{K}$, and $\mathrm{CaCO}_{3}$ showed a significant difference between the three landforms. The alluvial fan site, which has a cover of biological crusts and a high percentage of higher vegetation, and the amount of nitrogen, potassium carbon and calcium carbonate in it is significantly higher than the oth- 


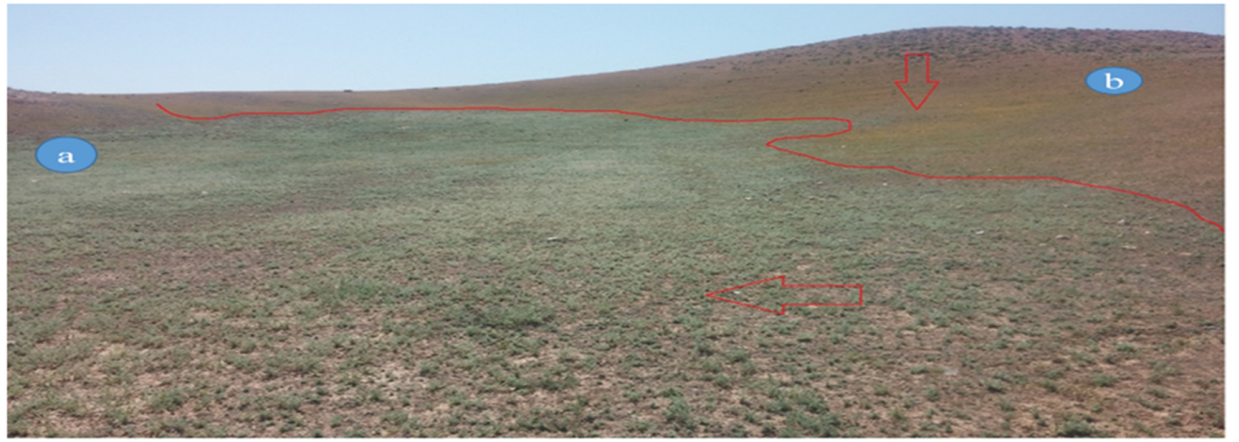

Fig. 5 Section (a) has a biological crust, and the presence of a nitrophilous plant (Amaranthaceae) indicates that the soil has a higher nitrogen content. Section (b) has no biological crust and its soil has less nitrogen. er two sites. Based on the results obtained, biological crusts are able to increase soil nitrogen by up to 200\% (DeFalco 1995). lichens and cyanobacteria fixate the atmospheric nitrogen and increase the soil nitrogen content up to 70\% and make it available to vascular plants, mosses, fungi, and other microbial soil communities (Gholamhosseinian et al. 2020; Harper and Belnap 2001) Therefore, they can have a significant impact on plant establishment and increase vegetation. Organic materials have a major role in determining the characteristics of the soil by affecting its physicochemical properties (Whalen and Chang 2002). The color change in Figure 5 of the two sections indicates that the site with biological crust has a darker color Figure $5 \mathrm{a}$ and is also covered with Amaranthaceae which is a nitrogenphilous plant. These observations express the fact that crusts increase nitrogen entrance to the soil through nitrogen fixation.

Biological crusts play an important role in the producing of organic carbon and the provision of a suitable substrate for plant growth by increasing soil carbon through the deposition of atmospheric carbon (Beymer and Klopatek 1991; Danin and Ganor 1991; Hassanzadeh et al. 2018). Cyanobacteria with polysaccharide secretions play an effective role in increasing carbon content (Mager and Thomas 2011) and decomposition of organic matter as well as increasing soil particle retention (Danin and Ganor 1991; Miralles et al. 2013). They can also convert carbon dioxide to calcium carbonate, so more calcium carbonate in the soil can be attributed to the higher amount of activity of this microorganism (Wierzchos et al. 2012). Gholamhosseinian et al. (2020) and Kheirfam (2020) also showed that the amount of organic carbon had increased significantly in the presence of moss and lichen crusts. The decrease in $\mathrm{pH}$ can be attributed to the increase in microbial respiration at the alluvial fan site (Chamizo et al. 2012). Potassium also adheres to the wall of lichens and is absorbed when moistened in the soil by negatively charged clays, which may explain the high amount of potassium on the site with lichen cover (Gholamhosseinian et al. 2020; Hassanzadeh et al. 2018).

\section{The impact of biological soil crusts on fertile islands development}

The highest variety of biological crusts was observed at an altitude of $770 \mathrm{~m}$ compared to other altitudes. At higher altitudes, due to better physicochemical soil conditions, the diversity of crusts decreased with decreasing altitude. The results also show that at this height, vegetation has decreased with decreasing diversity of crusts. Soil texture in alluvial fans is loamy and according to research, biological crusts have the highest growth rate in soils with medium texture (Kleiner and Harper 1972). In the terraced alluvial terrace and the hillslopes, the sand has increased more and is accompanied by a decrease in vegetation. The percentage of clay in the presence of biological crusts at the alluvial fan site was higher than the other two sites. This significant increase in the percentage of clay in the biocrusts compared with the bare soil can be attributed to dust capture in the biocrusts of the soil surface (Gholamhosseinian et al. 2021a).

The erosive effects at the alluvial fan site, which has more biological crust and vegetation cover, were much less than the other two sites. It absorbs the lichens of the elements and then introduces them into the soil, thus reducing the loss of elements due to leaching (Williams et al. 2013). Biological crusts are stabilized by polysaccharide secretion that binds soil particles (Fig. 4) (Zhang et al. 2016). Absorption of nutrients by polysaccharides is the mechanism by which cyanobacteria provide nutrients to plants (Belnap and Gardner 1993), and leads to the formation of Fertility Islands adjacent to the biological crusts (Fig. 4). Aggregate stability was significantly higher at the biological crusts site, due to the production of polysaccharides by cyanobacteria crusts that hold the particles together.

The results of the present study have revealed that the moisture content of the site with crust has had a significant increase compared to the other sites which could be due to the roughness caused by the biological crusts since they prolong the water retention time to a great extent and therefore increase the chance of permeability and runoff reduction (Belnap 2006). During precipitation, the polysaccharide plates present in cyanobacteria and algae are capable of rapidly absorbing water several times their weight (Bel- 
nap and Gardner 1993). The observations of Campbell (1980) and Verrecchia et al. (1995), showed that all of the biological crust absorb water in various degrees and increase the moisture of the soil, particularly cyanobacteria that absorb water over 10 times their volume and 8-12 times their weight. The results of the present study revealed that the stability of soil aggregates was significantly higher in the alluvial fan site, as compared to the other studied sites. The biological soil crusts play a major role in the stability of soil aggregates. Fungal hyphae, cyanobacterial filaments, and viscous lichen polysaccharides create a consistent network for the soil layers and stabilize the soil aggregates (Belnap et al. 2001; Chamizo et al. 2012; Maestre et al. 2011) and this stability protects soil aggregates against wind and water erosion (Eldridge and Greene 1994). As observed in Figure 4, algal biofilms and lichen are able to preserve soil particles, especially cyanobacteria which stabilize soil aggregates. Sepehr et al. (2019) also achieved similar results by investigating the effect of biological crusts on the stability and strength of aggregates.

The increased apparent density in soils lacking lichen cover is due to reduced biological activities and the low organic matter content of these soils. Therefore, the soil's reduced respiration, an index of the soil's biological activity, could be counted as one of the reasons influencing the increase of the soil's apparent density in the region (Niu et al. 2017). These results are in line with the studies of Jimenez et al. (2009), stating that the biological soil crusts have no type of competition with vascular plants, and this lack of competition leads to the availability of nutrients to the plants, thus promoting their establishment. Moreover, Tongway et al. (1989), observed a positive correlation between the vegetation percentage and the biological soil crusts and stated that by retaining the soil's moisture and nutrients and promoting fertility, these crusts are able to support the growth and establishment of plants. One of the most important spatial control factors of vegetation in natural ecosystems, other than the presence of biological soil crusts, is the microtopography of the studied site (Gholamhosseinian et al. 2021b). Microtopography directly impacts environmental factors such as altitude increase and temperature reduction and has an indirect effect on the formation of soil, plant communities, and their production (Thompson et al. 2005). The results of the present study showed that microtopography is the cause of vegetation patchiness in the fluvial terrace and hillslope sites.

\section{Conclusions}

The destruction of vegetation and the increase of coverless land is one of the signs of desertification. The biological soil crusts prevent the loss of nutrients by retaining the moisture obtained from runoff water, and increase soil fer- tility through the fixation of nitrogen and carbon, thus providing suitable conditions for the preservation and establishment of vegetation. They also develop fertile islands among plant patches, therefore reducing the distance between these patches which leads to a more uniform distribution in comparison to ecosystems that lack biological soil crusts. These fertile islands act as biological fertilizers and make nutrients available to plants, ultimately enhancing their growth. They also provide a suitable opportunity for the growth of other species, both annual and perennial, which leads to more diverse vegetation of the ecosystems. Furthermore, increased vegetation leads to the diversity of animal species and provides suitable conditions for herbivores.

\section{Abbreviations \\ BSCs: Biological soil crusts \\ EDS: Energy dispersive spectroscopy \\ SEM: Scanning electron microscope}

\section{Acknowledgements}

The authors are thanks from vice-president of the Ferdowsi University of Mashhad to consider financial support of the project.

\section{Authors' contributions}

AS collected the data, acquisition research grant, researched design, writing, review, and edited. AH collected the data, writing pre-original drafts. AGH analyzed and collected data, reviewed the paper, helped to write, and interpreted the results. $\mathrm{KN}$ collected the data. The authors read and approved the final manuscript.

\section{Funding}

The research was done by the a financial supported by Ferdowsi University of Mashhad (Grant Number: 3-47421).

\section{Availability of data and materials}

The datasets collected during and/or analyzed during the current study are available from the corresponding author on reasonable request.

\section{Ethics approval and consent to participate \\ Not applicable.}

\section{Consent for publication \\ Not applicable.}

\section{Competing interests}

The authors declare that they have no competing interests.

\section{References}

Belnap J, Büdel B, Lange OL. Biological soil crusts: characteristics and distribution. In: Belnap J, Lange OL, editors. Biological soil crusts: 
structure, function, and management. Berlin: Springer; 2001. p. 3-30.

Belnap J, Büdel B. Biological soil crusts as soil stabilizers. In: Weber B, Büdel B, Belnap J, editors. Biological soil crusts: an organizing principle in drylands. Cham: Springer; 2016. p. 305-20.

Belnap J, Gardner JS. Soil microstructure in soils of the Colorado Plateau: the role of the cyanobacterium Microcoleus vaginatus. Great Basin Nat. 1993;53(1):40-7.

Belnap J. The potential roles of biological soil crusts in dryland hydrologic cycles. Hydrol Process. 2006;20(15):3159-78. https://doi. org/10.1002/hyp.6325.

Belnap J. The world at your feet: desert biological soil crusts. Front Ecol Environ. 2003;1(4):181-9. https://doi.org/10.1890/1540-9295(2003)0 01[0181:TWAYFD]2.0.CO;2.

Beymer RJ, Klopatek JM. Potential contribution of carbon by microphytic crusts in pinyon-juniper woodlands. Arid Soil Res Rehabil. 1991;5(3):187-98. https://doi.org/10.1080/15324989109381279.

Bolling JD, Walker LR. Fertile island development around perennial shrubs across a Mojave desert chronosequence. West N Am Nat. 2002;62(1):88-100.

Bonanomi G, Rietkerk M, Dekker SC, Mazzoleni S. Islands of fertility induce co-occurring negative and positive plant-soil feedbacks promoting coexistence. Plant Ecol. 2008;197(2):207-18. https://doi. org/10.1007/s11258-007-9371-0.

Bouyoucos GJ. Hydrometer method improved for making particle size analyses of soils. Agron J. 1962;54(5):464-5. https://doi.org/10.2134/ agronj1962.00021962005400050028x.

Bowker MA, Koch GW, Belnap J, Johnson NC. Nutrient availability affects pigment production but not growth in lichens of biological soil crusts. Soil Biol Biochem. 2008;40(11):2819-26. https://doi.org/ 10.1016/j.soilbio.2008.08.002.

Bowker MA, Maestre FT, Escolar C. Biological crusts as a model system for examining the biodiversity-ecosystem function relationship in soils. Soil Biol Biochem. 2010;42(3):405-17. https://doi.org/10.1016/ j.soilbio.2009.10.025

Bremner J, Mulvaney C. Nitrogen- total. In: Page AL, editor. Methods of soil analysis: part 2 chemical and microbiological properties, 9.2.2. 2nd ed. Madison: American Society of Agronomy; 1983. p. 595-624.

Campbell SE. Soil stabilization by a prokaryotic desert crust: implications for Precambrian land biota. In: Ponnamperuma C, Margulis L, editors. Limits of life. Dordrecht: D. Reidel Publishing Company; 1980. p. 85-98.

Chamizo S, Cantón Y, Lázaro R, Solé-Benet A, Domingo F. Crust composition and disturbance drive infiltration through biological soil crusts in semiarid ecosystems. Ecosystems. 2012;15(1):148-61. https://doi.org/10.1007/s10021-011-9499-6.

Condon LA, Pyke DA. Fire and grazing influence site resistance to Bromus tectorum through their effects on shrub, bunchgrass and biocrust communities in the Great Basin (USA). Ecosystems. 2018;21(7): 1416-31. https://doi.org/10.1007/s10021-018-0230-8.

Danin A, Ganor E. Trapping of airborne dust by mosses in the Negev Desert, Israel. Earth Surf Process Landf. 1991;16(2):153-62. https:// doi.org/10.1002/esp.3290160206.

DeFalco LA. Influence of cryptobiotic soil crusts on annual plants and foraging movements of the desert tortoise in the northeast Mojave
Desert [Doctoral dissertation]. Fort Collins: Colorado State University; 1995.

Eldridge DJ, Greene RS. Microbiotic soil crusts - a review of their roles in soil and ecological processes in the rangelands of Australia. Aust J Soil Res. 1994;32(3):389-415. https://doi.org/10.1071/SR9940389.

Gholamhosseinian A, Sepehr A, Emadodin I. The effects of biocrusts on soil parameters in a semi-arid pediment at north-eastern Iran. Rev Geomorfol. 2020;22(1):5-19. https://doi.org/10.21094/rg.2020.094.

Gholamhosseinian A, Sepehr A, Lajayer BA, Delangiz N, Astatkie T. Biological soil crusts to keep soil alive, rehabilitate degraded soil, and develop soil habitats. In: Vaishnav A, Choudhary DK, editors. Microbial polymers. Singapore: Springer; 2021a. p. 289-309.

Gholamhosseinian A, Sepehr A, Sohrabi M, Emadodin I. Assessing the role of lichens in the prevention of dust emission in dryland: case study at north-eastern Iran. Aeolian Res. 2021b;50:100697. https:// doi.org/10.1016/j.aeolia.2021.100697.

Goldstein JI, Newbury DE, Michael JR, Ritchie NWM, Scott JHJ, Joy DC. Scanning electron microscopy and X-ray microanalysis. 4th ed. New York: Springer; 2018.

Harper KT, Belnap J. The influence of biological soil crusts on mineral uptake by associated vascular plants. J Arid Environ. 2001;47(3): 347-57. https://doi.org/10.1006/jare.2000.0713.

Hashtroudi MS, Shariatmadari Z, Riahi H, Ghassempour A. Analysis of Anabaena vaginicola and Nostoc calcicola from Northern Iran, as rich sources of major carotenoids. Food Chem. 2013;136(3-4):114853. https://doi.org/10.1016/j.foodchem.2012.09.055.

Hassanzadeh Bashtian M, Sepehr A, Farzam M, Bahreini M. Distribution of biological soil crust along surface evolution of an arid alluvial fan. Res Earth Sci. 2018;9(1):1-13. https://doi.org/10.29252/esrj.9.1.1.

Hayat MA, Abd Kudus K, Faridah-Hanum I, Awang Noor AG, Nazre M. Assessment of plant species diversity at Pasir Tengkorak Forest Reserve, Langkawi Island, Malaysia. J Agric Sci. 2010;2(1):31-8. https://doi.org/10.5539/jas.v2n1p31.

Jimenez AA, Huber-Sannwald E, Belnap J, Smart DR, Arredondo MJT. Biological soil crusts exhibit a dynamic response to seasonal rain and release from grazing with implications for soil stability. J Arid Environ. 2009;73(12):1158-69. https://doi.org/10.1016/j.jaridenv.2009. 05.009.

Kheirfam H. Increasing soil potential for carbon sequestration using microbes from biological soil crusts. J Arid Environ. 2020;172:104022. https://doi.org/10.1016/j.jaridenv.2019.104022.

Kleiner EF, Harper KT. Environment and community organization in grasslands of Canyonlands National Park. Ecology. 1972;53(2):299309. https://doi.org/10.2307/1934086.

Knudsen D, Peterson GA, Pratt PF. Lithium, sodium, and potassium. In: Page AL, editor. Methods of soil analysis: part 2 chemical and microbiological properties, 9.2.2. 2nd ed. Madison: American Society of Agronomy; 1983. p. 225-46.

Lax A, Díaz E, Castillo V, Albaladejo J. Reclamation of physical and chemical properties of a salinized soil by organic amendment. Arid Soil Res Rehabil. 1994;8(1):9-17.

Ludwig JA, Bastin GN, Chewings VH, Eager RW, Liedloff AC. Leakiness: a new index for monitoring the health of arid and semiarid landscapes using remotely sensed vegetation cover and elevation 
data. Ecol Indic. 2007;7(2):442-54. https://doi.org/10.1016/j.ecolind. 2006.05.001.

Maestre FT, Bowker MA, Cantón Y, Castillo-Monroy AP, Cortina J, Escolar $\mathrm{C}$, et al. Ecology and functional roles of biological soil crusts in semi-arid ecosystems of Spain. J Arid Environ. 2011;75(12):128291. https://doi.org/10.1016/j.jaridenv.2010.12.008.

Mager DM, Thomas AD. Extracellular polysaccharides from cyanobacterial soil crusts: a review of their role in dryland soil processes. J Arid Environ. 2011;75(2):91-7. https://doi.org/10.1016/j.jaridenv.2010. 10.001 .

McCune B, Divakar PK, Upreti DK. Hypogymnia in the Himalayas of India and Nepal. Lichenologist. 2012;44(5):595-609. https://doi. org $/ 10.1017 /$ S0024282912000321.

Mingorance MD, Barahona E, Fernández-Gálvez J. Guidelines for improving organic carbon recovery by the wet oxidation method. Chemosphere. 2007;68(3):409-13. https://doi.org/10.1016/j.chemosphere.2007.01.021.

Miralles I, Trasar-Cepeda C, Leirós MC, Gil-Sotres F. Labile carbon in biological soil crusts in the Tabernas desert, SE Spain. Soil Biol Biochem. 2013;58:1-8. https://doi.org/10.1016/j.soilbio.2012.11.010.

Muñoz-Rojas M, Román JR, Roncero-Ramos B, Erickson TE, Merritt DJ, Aguila-Carricondo P, et al. Cyanobacteria inoculation enhances carbon sequestration in soil substrates used in dryland restoration. Sci Total Environ. 2018;636:1149-54. https://doi.org/10.1016/j.scitotenv.2018.04.265.

Nelson DW, Sommers LE. Total carbon, organic carbon, and organic matter. In: Sparks DL, Page AL, Helmke PA, Loeppert RH, Soltanpour PN, Tabatabai MA, et al. editors. Methods of soil analysis: part 3 chemical methods, 5.3. Madison: Soil Science Society of America; 1996. p. 961-1010.

Niu J, Yang K, Tang Z, Wang Y. Relationships between soil crust development and soil properties in the desert region of North China. Sustainability. 2017;9(5):725. https://doi.org/10.3390/su9050725.

O'Callaghan A, van Sinderen D. Bifidobacteria and their role as members of the human gut microbiota. Front Microbiol. 2016;7:925. https:// doi.org/10.3389/fmicb.2016.00925.

Olsen SR. Estimation of available phosphorus in soils by extraction with sodium bicarbonate. Washington, D.C.: US Department of Agriculture; 1954.

Rayment GE, Lyons DJ. Soil chemical methods: Australasia. Collingwood: CSIRO Publishing; 2011.

Rosentreter R, Bowker M, Belnap J. A field guide to biological soil crusts of western U.S. drylands: common lichens and bryophytes. Denver: U.S. Government Printing Office; 2007.

Schlesinger WH, Reynolds JF, Cunningham GL, Huenneke LF, Jarrell WM, Virginia RA, et al. Biological feedbacks in global desertification. Science. 1990;247(4946):1043-8. https://doi.org/10.1126/science.247.4946.1043.

Sepehr A, Hassanzadeh M, Rodriguez-Caballero E. The protective role of cyanobacteria on soil stability in two Aridisols in northeastern Iran.
Geoderma Reg. 2019;16:e00201. https://doi.org/10.1016/j.geodrs. 2018.e00201.

Shannon CE. A mathematical theory of communication. Bell Syst Tech J. 1948;27(3):379-423. https://doi.org/10.1002/j.1538-7305.1948. tb01338.x.

Simpson EH. Measurement of diversity. Nature. 1949;163:688. https:// doi.org/10.1038/163688a0.

Temina M, Nevo E. Lichens of Israel: diversity, ecology, and distribution. BioRisk. 2009;3:127. https://doi.org/10.3897/biorisk.3.25.

Thompson DB, Walker LR, Landau FH, Stark LR. The influence of elevation, shrub species, and biological soil crust on fertile islands in the Mojave Desert, USA. J Arid Environ. 2005;61(4):609-29. https:// doi.org/10.1016/j.jaridenv.2004.09.013.

Tongway DJ, Ludwig JA, Whitford WG. Mulga log mounds: fertile patches in the semi-arid woodlands of eastern Australia. Aust J Ecol. 1989;14(3):263-8. https://doi.org/10.1111/j.1442-9993.1989.tb01436. $\mathrm{x}$.

Toranjzar H, Abedi M, Ahmadi A, Ahmadi Z. Assessment of rangeland condition (health) in Meyghan desert of Arak. Rangeland. 2009;3(2): 259-71.

Verrecchia E, Yair A, Kidron GJ, Verrecchia K. Physical properties of the psammophile cryptogamic crust and their consequences to the water regime of sandy soils, north-western Negev Desert, Israel. J Arid Environ. 1995;29(4):427-37. https://doi.org/10.1016/S0140-1963(95) 80015-8.

Walker LR, Thompson DB, Landau FH. Experimental manipulations of fertile islands and nurse plant effects in the Mojave Desert, USA. West N Am Nat. 2001;61(1):25-35.

Whalen JK, Chang C. Macroaggregate characteristics in cultivated soils after 25 annual manure applications. Soil Sci Soc Am J. 2002;66(5): 1637-47. https://doi.org/10.2136/sssaj2002.1637.

Wierzchos J, de los Ríos A, Ascaso C. Microorganisms in desert rocks: the edge of life on Earth. Int Microbiol. 2012;15(4):173-83. https:// doi.org/10.2436/20.1501.01.170.

Williams AJ, Buck BJ, Soukup DA, Merkler DJ. Geomorphic controls on biological soil crust distribution: a conceptual model from the Mojave Desert (USA). Geomorphology. 2013;195:99-109. https://doi. org/10.1016/j.geomorph.2013.04.031.

Zedda L. Lecanora leuckertiana sp. nov. (lichenized Ascomycetes, Lecanorales) from Italy, Greece, Morocco and Spain. Nova Hedwig. 2000;71(1-2):107-12. https://doi.org/10.1127/nova/71/2000/107.

Zhang Y, Aradottir AL, Serpe M, Boeken B. Interactions of biological soil crusts with vascular plants. In: Weber B, Büdel B, Belnap J, editors. Biological soil crusts: an organizing principle in drylands. Cham: Springer; 2016. p. 385-406.

Zhao HL, Guo YR, Zhou RL, Drake S. Biological soil crust and surface soil properties in different vegetation types of Horqin Sand Land, China. CATENA. 2010;82(2):70-6. https://doi.org/10.1016/j.catena.2010.05.002. 